\title{
What is the Effect of 90-Degree Double- Plate Fixation with Grafting on Healing of Humeral Shaft Non-unions
}

\author{
Doksan Derece Konumlandırılmış Çift Plak ile Tespit ve \\ Greftlemenin Humerus Cisim Kaynama Yokluğunun Iyileşmesi \\ Üzerine Etkinliği Nedir?
}

\author{
Mutlu Çobanoğlu ${ }^{1}$, Özgür Özbey ${ }^{2}$, Öner Şavk ${ }^{1}$, Ferit Özgezmez ${ }^{1}$ \\ ${ }^{1}$ Adnan Menderes University Faculty of Medicine, Department of Orthopedics and Traumatology, Aydın, Turkey \\ ${ }^{2}$ Zonguldak State Hospital, Clinic of Orthopedics and Traumatology, Zonguldak, Turkey
}

Keywords

Humeral fractures, non-union, double-plate fixation

Anahtar Kelimeler

Humerus kırığı, kaynamama, çift-plak tespiti

Received/Geliş Tarihi : 21.03.2016

Accepted/Kabul Tarihi : 29.03.2016

doi:10.4274/meandros.2724

Address for Correspondence/Yazışma Adresi: Mutlu Çobanoğlu MD,

Adnan Menderes University Faculty of Medicine, Department of Orthopedics and Traumatology, Aydın, Turkey

Phone : +90 5323876057

E-mail :drmutlu79@hotmail.com

C. Meandros Medical and Dental Journal, published by Galenos Publishing.

(c) Meandros Medical and Dental Journal, Galenos Yayınevi tarafından basılmışıır.

\begin{abstract}
Objective: Our aim was to investigate the clinical and radiological outcomes of double-plate fixation with grafting in the treatment of non-union of humeral shaft fractures.

Materials and Methods: We performed a retrospective chart review of patients operated between 2006 and 2012 due to humeral shaft non-union. Patients undergoing surgery with double-plate fixation were included and those treated with external fixator, single plate, intramedullary nails and patients with pathological fractures and infected non-unions were excluded. Surgical intervention via anterolateral or posterior approach included radial nerve identification, decortication and reestablishment of medullary canal followed by compression plating with double-plate fixation and frequent application of autogenous grafts or allografts. Main outcome measures were success rate of non-union repair, rate of re-intervention and complications, range of motion, assessment of pain Visual analogue scale (VAS) and function Disabilities of the arm, shoulder and hand (DASH) and overall outcome Stewart-Hundley classification.

Results: Ten patients were treated with double-plate fixation. The study group included six females and four males aged 36 to 70 years. Union was achieved within 4.5 and 8 months in all cases. The mean preoperative VAS score of 6.1 decreased to 2, postoperatively, with an associated decrease in the mean DASH score from 74.1 to 23.4. Excellent or good results were obtained in nine cases. There was no incidence of radial nerve palsy or infection.

Conclusion: Our study provides level 4 evidence of the effectiveness of treating non-union fractures of the humeral shaft with double-plate fixation and grafting in providing good-to-excellent functional results and high union rate without any significant complication.
\end{abstract}

Öz

Amaç: Çalışmanın amacı, humerus cisim kırıkları sonrası gelişen kaynama yokluğunun (non-union), çift plak tespiti ve greftleme ile tedavisinden elde edilen radyolojik ve klinik sonuçları değerlendirmektir. 
Gereç ve Yöntemler: Humereus cisim non-union nedeniyle 2006 ve 2012 yılları arasında ameliyat edilen olgular retrospektif olarak değerlendirildi. Sadece çift plak tespiti uygulanan olgular çalışmaya dahil edildi. Eksternal fiksatör ile tespit, tek plak ile tespit, intramedüller tespit uygulanan olgular ile patolojik kırık nedeniyle ameliyat edilen olgular çalışmaya dahil edilmedi. Anterolateral veya posterior yaklaşımla uygulanan cerrahi teknik, radial sinir diseksiyonunu, dekortikasyonu, medüller kanalın yeniden oluşturulmasını, çift plak ile tespiti ve otojen veya allojen greft uygulamasını içermekteydi. Sonuçların değerlendirmesinde, non-union onarımının başarısı, tekrar cerrahi ve komplikasyon oranı, eklem hareket açıkı̆̆ı, görsel ağrı ölçütü (GAS), fonksiyon ölçütleri (DASH) ve StewartHundley sınıflaması kullanıldı.

Bulgular: Çalışmada çift plak tespiti uygulanan on olgu mevcuttu. Olgulardan altısı kadın, dördü erkekti. Kaynama tüm olgularda 4,5-8 ayda gerçekleşti. Ameliyat sonrası radial sinir felci veya enfeksiyon görülmedi. GAS ortalama 6,1'den 2'ye, DASH skoru 74,1'den 23,4'e geriledi. Dokuz olguda iyi ve mükemmel sonuç elde edildi.

Sonuç: Çalışma, seviye 4 kanıt değerine sahip olup humerus cisim non-union olgularında çift plak tespit ve greftleme ile tedavinin, ciddi düzeyde komplikasyonu olmayan, yüksek kaynama oranına sahip, iyi ve mükemmel sonuçlar sağlayan bir yöntem olduğunu göstermektedir.

\section{Introduction}

Non-union remains a significant complication of humeral shaft fractures, which has negative effects on patients' psychosocial status and health economics, as well as leading to loss of manpower. Non-union of humeral shaft fractures occurs in $2 \%$ to $10 \%$ of cases treated conservatively and in up to $15 \%$ of cases treated surgically (1-3). Recent developments in the field of implant technology and surgical techniques have led to successful results in surgical treatments of humeral shaft fractures (4). Several methods have been reported to deal specifically with non-union, such as compression plating and bone grafting (5$7)$, vascularized fibular grafting $(1,8)$, intramedullary nailing (9), and circular external fixation (10). Of these, the most successful treatment is open reduction and internal fixation using compression plating and autologous bone grafting $(5,6,8,11-13)$. However, poor bone quality secondary to aging, disuse, and previous surgery may lead to inadequate screw purchase, poor stabilization, mechanical failure, and persistent non-union. To obtain sufficient bone healing, rigid stabilization that maintains solid bone contact and compression between the fracture ends is necessary in these cases. To increase stability, different techniques, including dynamic compression plate (DCP) with cancellous bone grafting (5), DCP with cortical strut allografts (8) and double-plate fixation with grafting have been used (14). There is evidence that among these techniques, double-plate fixation creates a more stable construct than single plate fixation (12). Due to the high stability it provides, double-plate fixation may be an optimal technique to deal with non-union of humeral shaft fractures. Therefore, the aim of our study was to evaluate the clinical outcomes of double-plate fixation and grafting for non-union of humeral shaft fractures.

\section{Materials and Methods}

Our study was approved by our institution's Ethics Review Board. We performed a retrospective chart review of patients who were treated for non-union of humeral shaft fractures at our institution between 2006 and 2012. Thirty cases of humerus fractures were identified, in which initial fracture had been treated, either conservatively or surgically, in other institutions. Of these, 21 cases were fractures of the humeral shaft. Cases in which non-unions were treated with external fixator, single plate fixation, and intramedullary nail, as well as cases with pathological fractures and infected non-unions, were excluded. One case of a distal humeral shaft non-union fracture treated with medial and lateral plate fixation via a posterior approach with olecranon osteotomy was also excluded. Therefore, our analysis was based on the data of ten cases of non-union of mid-shaft fracture of the humerus.

Medical chart review was performed to extract relevant information from the history and physical examination to identify fracture etiology. The following preoperative information was identified for analysis: pain [Visual analogue scale (VAS)] and functional scores, [Disabilities of the arm, shoulder and hand (DASH)]; time from occurrence of fracture to non-union repair; preoperative range of motion of the shoulder and elbow joints; nerve injuries or other pathologies which were investigated. Postoperative information included: salient findings from the final examination and functional status assessed by the 
VAS and DASH, and overall rating of outcomes using the Stewart and Hundley classification (14).

\section{Surgical Technique}

All surgeries were performed under general anesthesia. Thirty minutes before surgery, intravenous (iv) cefazolin sodium $1 \mathrm{~g}$ was administered. Surgical site cleaning was done outside the operating room. After cleaning the surgical site, the hand and forearm were encased in a sterile stockinette. The surgical area was covered with an iodine-impregnated drape. An anterolateral approach was used in four patients and a posterior approach in six. Thorough debridement of the sclerotic bone and any fibrotic tissue was performed until bleeding of the bone was obtained. The intramedullary canal was reestablished by drilling. The fragments were reduced and stable fixation was achieved with two plates lying at $90^{\circ}$ to each other. The first DCP locking plate was placed either on the anterior or posterior surface, depending on the approach used, and the second was placed on the lateral surface of the bone, perpendicular to the first plate. After fixation, cancellous bone grafts from the iliac crest were used in three cases and granules (TCH 2-3 mm pellets) were packed around the nonunion site in the other seven cases to support the biological healing. Demineralized bone matrix (Putty Allogenix W. Lorenz) was mixed with the granules in one of these seven cases and granular calcium phosphate (Callos-Biomet) was mixed with granules in another. No suction drain was used. A splint was applied from the metacarpophalangeal joint up to the level of the shoulder. After surgery, $4 \times 1$ /day $500 \mathrm{mg}$ of paracetamol and Xefo (Lornoxicam $8 \mathrm{mg}$ ) was administered by iv $1 \times 1 /$ day for pain control.
Antibiotic prophylaxis using cefazolin sodium $4 \times 1$ g/day was administered until postoperative day 3. None of the patients had postoperative wound problems. When postoperative pain was tolerable, the splint was removed and passive shoulder, elbow, and wrist exercises were started under supervision of a physiotherapist. Radiographs were repeated at postoperative months $1,3,6$, and 12 . Healing was defined as the presence of a bridging callus on at least three cortices on two radiographic views (anteroposterior and lateral views) and absence of graft lysis.

\section{Statistical Analysis}

For the limited number of patients, descriptive statistical methods were used for analysis.

\section{Results}

Relevant demographic and clinical features of the patients forming our study group are summarized in Table 1. The study group included six females and four males with a mean age of 52.6 years (range: 36-70 years). One patient had a history of hypertension and one patient with hemiplegia had a history of epilepsy. The etiology of fractures included low-energy trauma (two patients), motor vehicle accident (six patients), and falling from a height (two patients). One patient had been treated conservatively and nine patients had undergone one-to-three surgeries in an attempt to obtain union of the fracture before admission to our institution (Figure 1). Previous surgical treatment included intramedullary nail fixation, external fixation and single-plate fixation. The average time between initial fracture and non-union repair was 46.5 months (range: 6 to 102 months) (Figure 2). The mean follow up time after non-union repair was $\mathbf{4 5 . 7}$ months (range:
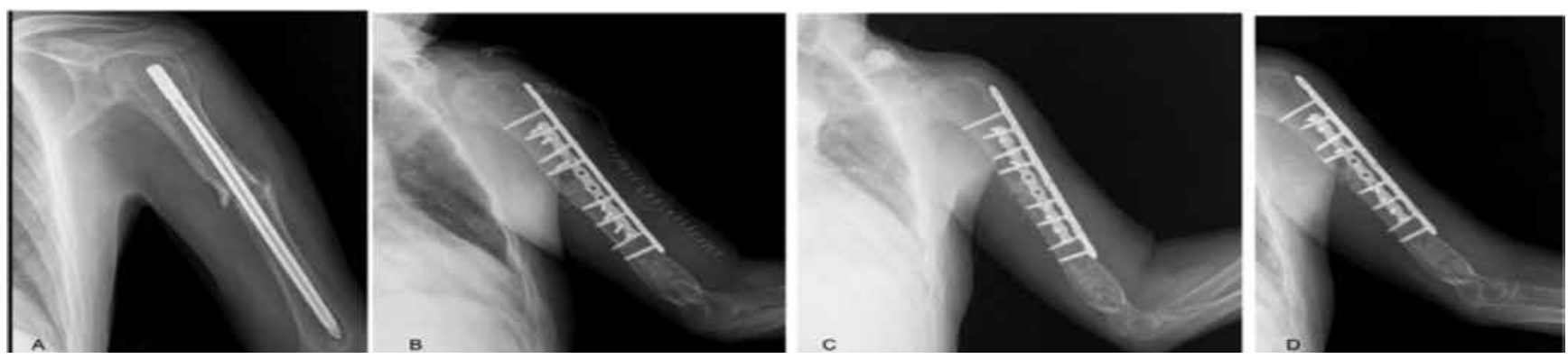

Figure 1. A left humeral shaft fracture, sustained during a fall, in a 54 year old man, with initial treatment with intramedullary nail. The non-union repair was performed 80 months later and included removal of the nail, decortication, autogeneous bone grafts, and two-plate fixation. A) Radiolucent area around the nail was present on the preoperative lateral radiograph; B) radiograph immediately after surgery; C) radiograph at 1 month, postoperatively; and D) radiograph at 3 months postoperatively, showing evidence of fracture consolidation 

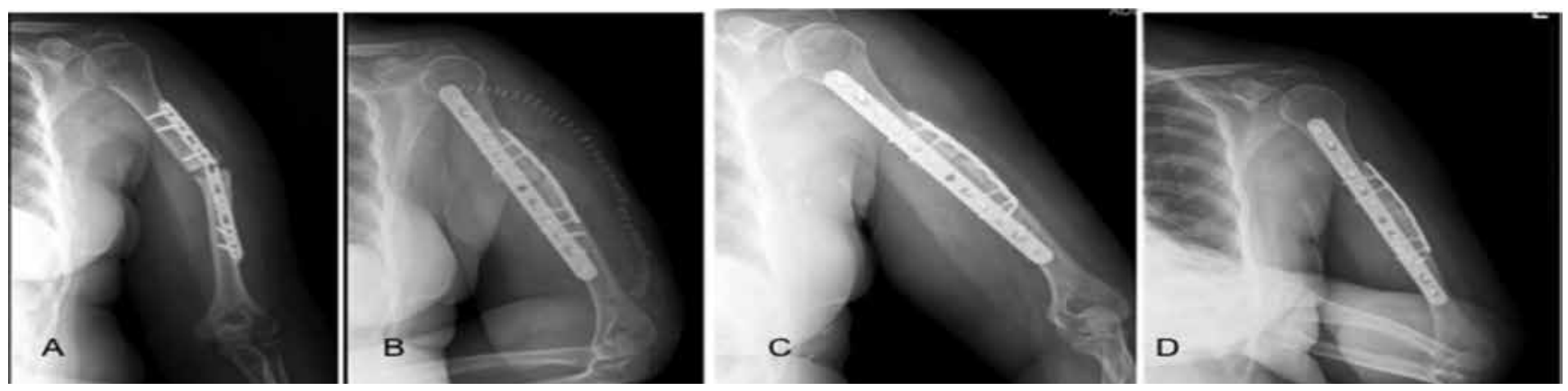

Figure 2. Left humeral shaft fracture in a 59-year-old woman involved in a motor vehicle accident, with initial treatment using single plate fixation. The non-union repair was performed 19 months after the initial repair an included removal of the plate, decortication, autogenous bone grafts, and two-plate fixation. A) Preoperative antero-posterior radiograph showing implant failure and non-union of the transverse humeral mid-shaft fracture; B) radiography immediately after the non-union repair; C) radiograph at 3 months postoperatively, showing radiological consolidation; and D) radiograph at 12 months postoperatively, showing union without implant failure and with no patient-reported complaints

\begin{tabular}{|c|c|c|c|c|c|c|c|}
\hline Patient no & Age & $\begin{array}{l}\text { Type of } \\
\text { trauma }\end{array}$ & $\begin{array}{l}\text { Previous treatment } \\
\text { (number) }\end{array}$ & Surgical approach & Type of graft & $\begin{array}{l}\text { Follow-up } \\
\text { (month) }\end{array}$ & $\begin{array}{l}\text { Time to union } \\
\text { (month) }\end{array}$ \\
\hline 1 & 59 & MVA & $\mathrm{PF}(1)$ & Posterior & $\begin{array}{l}\text { Allograft } \\
\text { (granule) }\end{array}$ & 70 & 4.5 \\
\hline 2 & 36 & MVA & $\mathrm{PF}(1)$ & Posterior & Autograft & 59 & 6 \\
\hline 3 & 48 & MVA & $\operatorname{EF}(1), \operatorname{EFR}(1) \operatorname{PF}(1)$ & Posterior & Autograft & 57 & 5.5 \\
\hline 4 & 70 & FD & $\mathrm{PF}(2)$ & Anterolateral & $\begin{array}{l}\text { Allograft } \\
\text { (granule) }\end{array}$ & 51 & 7 \\
\hline 5 & 39 & FD & Conservative (brace) & Posterior & $\begin{array}{l}\text { Allograft } \\
\text { (granule) }\end{array}$ & 50 & 6 \\
\hline 6 & 49 & MVA & PF (3) & Posterior & $\begin{array}{l}\text { Allograft } \\
\text { (granule) }\end{array}$ & 50 & 6.5 \\
\hline 7 & 58 & MVA & $\mathrm{PF}(2)$ & Posterior & $\begin{array}{l}\text { Allograft } \\
\text { (granule and } \\
\text { DBM) }\end{array}$ & 46 & 5 \\
\hline 8 & 53 & MVA & IMN (1), PF (1) & Anterolateral & $\begin{array}{l}\text { Allograft } \\
\text { (granule and } \\
\text { callos) }\end{array}$ & 38 & 5.5 \\
\hline 9 & 60 & FD & $\mathrm{PF}(2)$ & Anterolateral & Autograft & 13 & 6 \\
\hline 10 & 54 & FD & IMN (1) & Anterolateral & $\begin{array}{l}\text { Allograft } \\
\text { (granule) }\end{array}$ & 13 & 6 \\
\hline
\end{tabular}

13 to 70 months). The average time between the first examination and surgical repair was 5.7 days (range: 2 to 13 days). Patients were discharged on average 3.9 days (range: 3 to 6 days) after surgery. Long arm splints were removed on average of 20.1 days (range: 15 to 30 days) after surgery. Union was achieved in all ten cases, with a mean time to union of 5.8 months (range: 4.5 to 8 months). Functional outcomes of patients were evaluated, pre- and postoperatively, except for the patient with hemiplegia. The results are summarized in Table 2. Both the VAS and DASH scores improved postoperatively, with a change in VAS score from 6.1 (range: 5-8) preoperatively to 2 (range: 1-4) postoperatively, and a change in DASH score from 


\begin{tabular}{|c|c|c|c|c|c|c|}
\hline \multirow{2}{*}{ Patient no } & \multicolumn{2}{|l|}{ VAS } & \multirow[t]{2}{*}{ Range of motion* } & \multirow[t]{2}{*}{ Result* } & \multicolumn{2}{|l|}{ DASH } \\
\hline & Preoperative & Postoperative & & & Preoperative & Postoperative \\
\hline 1 & 7 & 1 & Shoulder and elbow excellent & Excellent & 84 & 16 \\
\hline 2 & 6 & 2 & Shoulder and elbow excellent & Excellent & 66 & 24 \\
\hline 3 & 7 & 1 & Shoulder and elbow excellent & Excellent & 84 & 18 \\
\hline 4 & 7 & 2 & Shoulder and elbow excellent & Excellent & 66 & 20 \\
\hline 6 & 5 & 2 & $\begin{array}{l}\text { Shoulder excellent, elbow } \\
\text { good }\end{array}$ & Excellent & 62 & 22 \\
\hline 7 & 8 & 2 & $\begin{array}{l}\text { Shoulder excellent, elbow } \\
\text { moderate }\end{array}$ & Excellent & 86 & 24 \\
\hline 8 & 8 & 4 & $\begin{array}{l}\text { Shoulder good, elbow } \\
\text { moderate }\end{array}$ & Excellent & 76 & 36 \\
\hline 9 & 8 & 2 & Shoulder and elbow excellent & Good & 78 & 26 \\
\hline 10 & 5 & 2 & Shoulder and elbow excellent & Excellent & 66 & 25 \\
\hline
\end{tabular}

74.1 (range: 62-86) preoperatively to 23.4 (range: 16-36) postoperatively. According to the Steward and Hundley classification, postoperative range of motion of the shoulder was excellent in eight patients and good, in one with range of motion at the elbow excellent in six patients, good in one and moderate in two. Patients with good and moderate elbow range of motion postoperatively had different degrees of flexion contractures in elbow joints preoperatively. For the eight patients with excellent outcomes, there were no indications of malalignment or of injury to the radial nerve.

\section{Discussion}

Poor bone quality or bone stock due to disuse, osteoporosis and previous surgery, in combination with fibrotic tissues around neurovascular structures, increase the difficulty in effective treatment of nonunion of humeral shaft fractures. In patients with low bone quality, providing stability between the ends of the fracture is the most important component of the surgical management (15). Currently, various techniques have been described in the clinical literature to provide sufficient stability, including the use of interlocking nails, unilateral or circular external fixator, and plates $(5,14,16-18)$. However, the rate of union using reaming and exchange nails has been reported to vary widely, between 40 and $100 \%(13,18)$. Furthermore, interlocking intramedullary nails do not provide the necessary rotational and axial stability to achieve consolidation of non-union humeral fracture (11). Unlike a fresh humeral fracture, intramedullary fixation of a pseudo-arthrosis is technically difficult due to disruption in bony alignment and fibrotic tissues (7). Unilateral external fixator may be used temporarily for infected non-unions, and there is evidence of superior outcomes using circular external fixation, compared to internal fixation systems, when the non-union is complicated by deformity, infection, bone loss, and length discrepancy (16). However, plate fixation is considered to be the gold standard for the treatment of non-unions of humeral shaft fractures. Plate fixation offers several advantages, including compression, correction of axis and stimulation of osteogenesis with grafting in one-stage procedure. Among various plating techniques, healing rates have been reported to vary between 92 and 100\% using compression plating in combination with autogenous grafting $(6,12)$. Different types of plate fixation with grafting have been described. Van Houwelingen and McKee (8) and Hornicek et al. (6) evaluated the use of cortical allograft struts to treat humeral shaft nonunions complicated by severe osteopenia. Crosby et al. (19) have reported that the use of compression plating with intramedullary fibular allografting in twelve patients with osteoporosis and proximal nonunion of humeral shaft fractures provided union in ten patients (83.2\%). However, these techniques may 
not be widely available due to costs and availability of health insurance. A vascularized fibular graft also has been recommended for humeral shaft non-union, but routine use of this technique is limited by availability of conditions and expertise. Therefore, this technique should be performed only for very complex cases (1). Mckee et al. (13) have reported outcome of plating and bone grafting in nine patients in whom an union rate of $100 \%$ was achieved. Ring et al. (15) have presented the outcome of plate-and-screw fixation and application of an autogenous bone graft from the iliac crest in 22 elderly patients with non-union of osteoporotic humeral shaft fractures and reported that a union rate of $91 \%$ was achieved within 6 months. A double-plate fixation construct provides another approach to increase stability across the region of non-union. Rubel et al. (12) evaluated biomechanical and clinical outcomes of single and double-plate fixation systems used in the management of nonunions of humeral shaft fractures. They reported that although double-plate constructs were significantly stiffer than single-plate constructs, there was no significant difference in healing rate and clinical outcomes between the two constructs, with an overall healing rate of $92 \%$ achieved without complications within 4.8 months, on average. Based on their results, Rubel et al. (12) suggested that if rigid stabilization of the humerus at the mid-shaft is needed to optimize healing, then a double-plate construct would be mechanically stiffer than a single-plate construct. Martinez et al. (14) evaluated outcome of doubleplate fixation (two $3.5 \mathrm{~mm}$ DCP plates) in 22 cases of non-union of humeral shaft fractures. Union was obtained within 4.6 months on average, with a $100 \%$ union rate attained, by 5.8 months on average. Of clinical importance was Martinez et al.'s (14) report of no bone necrosis, non-union and infection related to extensive dissection required in ten of their patients. Extensive dissection has been reported to increase the risk for complications, such as wound healing problems and non-union due to the disruption of the biology and nutrition of the fracture fragments (16). However, as correction of the local deformity of a non-union fracture is necessary, debridement of the non-union site, dissection of the radial nerve and extensive exposure for plating is mandatory. A wide exposure is required for two plates and, therefore, it has been recommended that exposure be limited to least six points of cortical fixation above and below the site of non-union for a single plate (20). Using double-plate fixation required exposure of more than six fixation points to increase stability in the same dissected area. We accomplished this with no complications related to wound healing or infection. Based on our outcomes, we propose that increasing sites of exposure to optimize stability may increase the risk of complications. This is in contrast to the report of Martinez et al. (14) who advocated that extensive dissection was not necessary to place two plates and that two-plate fixation without extensive dissection did not increase the rate of complication (14). Van Houwelingen and McKee (8) suggested that extensive periosteal stripping of the soft tissue could compromise the blood supply to the host humeral shaft, but they did not report any such effects to be clinically important. Although there was no radial nerve palsy in our series, it is important to be mindful that plate fixation does carry a high risk for radial nerve palsy, with an incident rate of about $20 \%$, due to extensive exposure required. However, most of palsies are transient, resolving within 6 to 7 months $(5,7,13-15,19)$. In terms of functional outcomes, we provided level 4 evidence of decreases in VAS and DASH scores postoperatively, findings comparable to previous reports. Ring et al. (15) reported that DASH score decreased from 77 to 24 points in their study, compared to 74.1 to 23.4 in our case series. Our rate of excellent or good results, based on the Stewart and Hundley classification, were comparable to rates reported by Martinez et al. (14).

\section{Study Limitations}

The limitations of this study include limited number of patients, no other comparable group, such as single plate or nail fixation, and the use of different types of grafts. However, our analysis was based on ten cases of non-union with various fracture etiologies and over a rather wide age group. Therefore, we do believe that our results provide homogenous information about double-plate fixation.

\section{Conclusion}

In this study, double-plate fixation with bone grafting resulted in a high union rate, providing good functional results with a low complication rate. This method provides a reliable surgical option for 
patients with humeral shaft non-unions who have poor bone quality or inadequate bone stock. The main advantages of this method include decreased morbidity, rigid stabilization with multipoint fixation and rapid return to independence.

\section{Ethics}

Ethics Committee Approval: The study were approved by the Adnan Menderes University Faculty of Medicine of Local Ethics Committee (2012/96), Informed Consent: This is a retrospective study. All material were collected from the records.

Peer-review: Internal peer-reviewed.

\section{Authorship Contributions}

Surgical and Medical Practices: Öner Şavk, Özgür Özbey, Concept: Öner Şavk, Mutlu Çobanoğlu, Design: Öner Şavk, Özgür Özbey, Data Collection or Processing: Özgür Özbey, Analysis or Interpretation: Mutlu Çobanoğlu, Özgür Özbey, Literature Search: Mutlu Çobanoğlu, Ferit Özgezmez, Writing: Mutlu Çobanoğlu, Ferit Özgezmez.

Conflict of Interest: No conflict of interest was declared by the authors.

Financial Disclosure: The authors declared that this study has received no financial support.

\section{References}

1. Jupiter JB. Complex non-union of the humeral diaphysis. Treatment with a medial approach, an anterior plate, and a vascularized fibular graft. J Bone Jt Surg Am 1990; 72: 701-7.

2. Rosen $\mathrm{H}$. The treatment of nonunions and pseudarthroses of the humeral shaft. Orthop Clin North Am 1990; 21: 725-42.

3. Sarmiento A, Kinman PB, Galvin EG, Schmitt RH, Phillips JG. Functional bracing of fractures of the shaft of the humerus. J Bone Joint Surg 2000; 59: 596-601.

4. Walker M, Palumbo B, Badman B, Brooks J, Van Gelderen J, Mighell M. Humeral shaft fractures: a review. J Shoulder Elbow Surg 2011; 20: 833-44.

5. Kumar A, Sadiq S. Non-union of the humeral shaft treated by internal fixation. Int Orthop 2002; 26: 214-6.

6. Hornicek FJ, Zych GA, Hutson JJ, Malinin TI. Salvage of humeral nonunions with onlay bone plate allograft augmentation. Clin Orthop Relat Res 2001; 386: 203-9.
7. te Velde EA, van der Werken C. Plate osteosynthesis for pseudarthrosis of the humeral shaft. Injury 2001; 32: 621-4.

8. Van Houwelingen AP, McKee MD. Treatment of osteopenic humeral shaft nonunion with compression plating, humeral cortical allograft struts, and bone grafting. J Orthop Trauma 2005; 19: 36-42.

9. Crolla RM, de Vries LS, Clevers GJ. Locked intramedullary nailing of humeral fractures. Injury 1993; 24: 403-6.

10. Patel VR, Menon DK, Pool RD, Simonis RB. Nonunion of the humerus after failure of surgical treatment. Management using the Ilizarov circular fixator. J Bone Joint Surg Br 2000; 82: 97783.

11. Marti RK, Verheyen CC, Besselaar PP. Humeral shaft nonunion: evaluation of uniform surgical repair in fifty-one patients. J Orthop Trauma 2002; 16: 108-15.

12. Rubel IF, Kloen P, Campbell D, Schwartz M, Liew A, Myers E, et al. Open reduction and internal fixation of humeral nonunions: a biomechanical and clinical study. J Bone Joint Surg Am 2002; 84: 1315-22.

13. McKee MD, Miranda MA, Riemer BL, Blasier RB, Redmond BJ, Sims $\mathrm{SH}$, et al. Management of humeral nonunion after the failure of locking intramedullary nails. J Orthop Trauma 1996; 10: 492-9.

14. Martinez AA, Cuenca J, Herrera A. Two-plate fixation for humeral shaft non-unions. J Orthop Surg (Hong Kong) 2009; 17: 135-8.

15. Ring D, Perey $B H$, Jupiter JB. The functional outcome of operative treatment of ununited fractures of the humeral diaphysis in older patients. J Bone Joint Surg Am 1999; 81: 177-90.

16. Padhye KP, Kulkarni VS, Kulkarni GS, Kulkarni MG, Kulkarni S, Kulkarni R, et al. Plating, nailing, external fixation, and fibular strut grafting for non-union of humeral shaft fractures. J Orthop Surg (Hong Kong) 2013; 21: 327-31.

17. Sioros VS, Lykissas MG, Pafilas D, Koulouvaris $P$, Mavrodontidis AN. llizarov treatment of humeral shaft nonunion in an antiepileptic drug patient with uncontrolled generalized tonicclonic seizure activity. J Orthop Surg Res 2010; 5: 48.

18. Kontakis GM, Papadokostakis GM, Alpantaki K, Chlouverakis G, Hadjipavlou AG, Giannoudis PV. Intramedullary nailing for nonunion of the humeral diaphysis: a review. Injury 2006; 37: 95360.

19. Crosby LA, Norris BL, Dao KD, McGuire MH. Humeral shaft nonunions treated with fibular allograft and compression plating. Am J Orthop 2000; 29: 45-7.

20. Healy WL, White GM, Mick CA, Brooker AF Jr, Weiland AJ. Nonunion of the humeral shaft. Clin Orthop Relat Res 1987; 219: 206-13. 